№ 1 (4), 2021

УДК 621.311

Г. М. Лисяк,

Національний університет "Львівська політехніка", кафедра електроенергетики та систем управління, georhii.m.lysiak@lpnu.ua

А. А. Маліновський, Національний університет “Львівська політехніка", кафедра електроенергетики та систем управління, anton.a.malinovskyi@lpnu.ua

O. Р. Пастух

Національний університет “Львівська політехніка”, кафедра електроенергетики та систем управління, olena.r.pastukh@lpnu.ua

\title{
РЕЖИМИ СХЕМИ ЖИВЛЕННЯ ВЛАСНИХ ПОТРЕБ ПІД ЧАС ПУСКІВ ЕНЕРГОБЛОКІВ З ДОДАТКОВИМ РОБОЧИМ ТРАНСФОРМАТОРОМ
}

http://doi.org/10.23939/sepes2021.01.052

(С Лисяк Г. М., Маліновський А. А., Пастух О. Р., 2021

Ефективність функціонування енергоблоків потужних теплових i атомних електростанцій великою мірою визначається надійністю систем живлення їхніх власних потреб. Основними вимогами до таких систем є підтримання необхідного рівня напруги на шинах розподільних устав власних потреб та зменшення часу вимушених перерв їх живлення. Забезпечення згаданих вимог українською енергетикою ускладнене тим, що більшість електростанцій експлуатується тривалий час, а їхнє устаткування суттєво зношене. У таких умовах актуальним с опрацювання і дослідження нових схемотехнічних вирішень систем живлення власних потреб блокових електростанцій. У роботі досліджено режими енергоблока під час його пуску із застосуванням додаткового робочого трансформатора власних потреб. Спосіб увімкнення такого трансформатора забезпечує його роботу в режимі джерела струму, заданого навантаженням енергоблока. Це дає змогу підтримувати необхідний рівень напруги на шинах власних потреб енергоблока як у тривалих експлуатаційних, так і під час аварійних режимів у зовнішній електричній мережі. Попередніми дослідженнями встановлено, що за обтяження режимів енергоблока напруга на шинах власних потреб також підтримується на достатньо високому рівні, що покращує забезпечення статичної та динамічної стійкості таких режимів порівняно з традиційними схемами живлення власних потреб. Для повноти інформації про нову систему живлення власних потреб необхідно дослідити ії режими для двох варіантів пуску енергоблока, що і є предметом цієї роботи. Обгрунтовано розрахункову схему заміщення системи власних потреб для обох варіантів пуску, сформовано і реалізовано відповідну математичну модель. Аналіз одержаних результатів показав, що під час пускових режимів забезпечусться належний рівень напруги на шинах розподільної устави першого ступеня трансформації схеми живлення електроприймачів власних потреб, а струмове навантаження 
елементів у кожному з характерних режимів не перевищує відповідних номінальних значень. Отже, підтверджена ефективність і доцільність упровадження схеми живлення власних потреб енергоблока з додатковим робочим трансформатором власних потреб.

Ключові слова: енергоблок; генератор; трансформатор; власні потреби; вимикач; режим пуску; моделювання; усталений режим; синхронізація.

\section{Постановка проблеми}

Від побудови схем живлення власних потреб енергоблоків електростанцій залежить надійність i стійкість технологічного процесу вироблення електроенергії. У низці праць вітчизняних і зарубіжних дослідників вирішено різні аспекти цієї проблеми [1-9]. Важливим також є оцінювання впливу рівня напруги в зовнішній електричній мережі на роботу електроприймачів власних потреб енергоблоків [10]. Можливим варіантом підвищення надійності їх функціонування енергоблоків $\epsilon$ досліджувана в роботі нова схема живлення 3 додатковим робочим трансформатором власних потреб [11], режими якої, зокрема під час пусків енергоблоків, потребують грунтовних наукових досліджень.

\section{Мета та завдання дослідження}

За допомогою комп'ютерного симулювання визначити параметри характерних квазіусталених режимів, які виникають під час пуску енергоблока $з$ додатковим робочим трансформатором власних потреб. Підтвердити, що в таких режимах забезпечується належний рівень напруги на шинах розподільних устав власних потреб як передумова успішного пуску енергоблока.

\section{Аналіз останніх досліджень}

Для продовження терміну експлуатації електростанцій, які працюють в Україні, необхідні нові схемотехнічні вирішення, щоб підвищити їхню надійність. Ефективність функціонування енергоблоків потужних електростанцій великою мірою визначається надійністю систем живлення електроприймачів їхніх власних потреб.

Запропонована в [9] схема передбачає застосування додаткового робочого трансформатора власних потреб та новий спосіб його увімкнення. В [12] запропонована методика оцінки необхідної встановленої потужності робочих трансформаторів першого ступеня трансформації схеми підвищеної надійності електропостачання власних потреб енергоблоків електростанцій. В [13-14] досліджено вплив цього трансформатора на забезпечення надійної роботи електроприймачів власних потреб під час нормальних експлуатаційних режимів та під час аварійних режимів у зовнішній електричній мережі. В [15] розроблено відповідні математичні моделі та алгоритми їхніх програмних реалізацій. Ефективність застосування додаткового робочого трансформатора власних потреб підтверджено порівняльним аналізом результатів експериментів на фізичній моделі та комп'ютерного симулювання [16]. 3 викладеного в $[17,18]$ про пускові режими енергоблоків 3 традиційними схемами живлення власних потреб випливає, що для повноти інформації про нову систему живлення власних потреб необхідно дослідити ії режими для характерних варіантів пуску енергоблока.

\section{Виклад основного матеріалу}

Принципова схема досліджуваного варіанта системи електропостачання власних потреб (ВП) енергоблока (ЕБ) з додатковим робочим трансформатором власних потреб (ДРТВП) [13] наведена на рис. 1. На ній прийнято такі позначення: Г - генератор; Т1 - блоковий трансформатор (БТ); Т2 робочий трансформатор ВП (РТВП); Т3 - додатковий робочий трансформатор ВП (ДРТВП); Т4 резервний або пускорезервний трансформатори ВП (РТВП або ПРТВП); Р - здвоєний реактор (в окремих випадках має несиметричні плечі або відсутній); $\mathrm{B}_{1} \div \mathrm{B}_{6}$ - вимикачі; РУВН - розподільна устава вищої напруги електростанції зв'язку з електроенергосистемою (ЕЕС); РУВП - розподільна устава ВП першого ступеня трансформації; РУ - розподільна устава електростанції, від якої живиться Т4; СШ - робоча система шин РУВП; СШР - система шин резервного живлення ВП від 
T4. Генератор Г через блоковий трансформатор Т1 та РУВН видає потужність в електроенергосистему. Електропостачання приймачів власних потреб здійснюється від генератора через робочий трансформатор власних потреб Т2 та через додатковий робочий трансформатор власних потреб Т3. Спосіб увімкнення останнього забезпечує його роботу в режимі заданого навантаженням ЕБ джерела струму. Дослідження, результати яких на прикладі енергоблока потужністю 200 МВт викладено в [13, 14], показали, що за відповідних технічних параметрів і характеристик електроустаткування рівень напруги на шинах РУВП буде в допустимих межах як в усталених експлуатаційних режимах, так і під час зовнішніх коротких замикань.

Згідно $з$ поставленим завданням нижче наведено зміст і результати досліджень умов забезпечення рівня напруги на шинах РУВП, необхідного для надійної роботи електроприймачів власних потреб, під час пускових режимів ЕБ з ДРТВП. Розглянемо два можливі варіанти пуску енергоблока 3 ДРТВП, які аналогічні варіантам пуску ЕБ з традиційними схемами живлення ВП [18].

Перший варіант. Пуск ЕБ за наявності генераторного вимикача $\mathrm{B}_{1}$ та Т4 як РТВП. На початковому етапі пуску ЕБ вимикач В $_{1}$ вимкнений. Живлення на робочу СШ РУВП подається від EЕС через РУВН електростанції, увімкнений вимикач $\mathrm{B}_{2}$, трансформатори $\mathrm{T} 1, \mathrm{~T} 2$, Т3 та увімкнений вимикач $\mathrm{B}_{3}$. Генератор Г вмикають на паралельну роботу з ЕЕС вимикачем $\mathrm{B}_{1}$. ПРТВП.

Другий варіант. Пуск ЕБ за відсутності генераторного вимикача $\mathrm{B}_{1}$ та наявності Т4 як

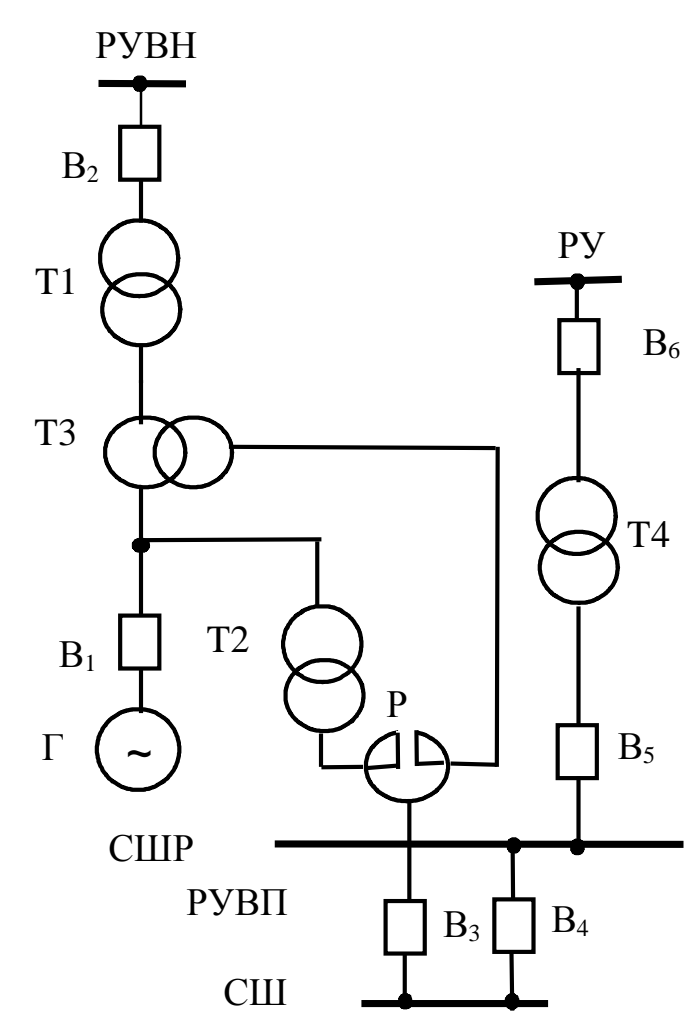

Рис. 1. Приничиова схема системи електропостачання ВП енергоблока з ДРТВП

На початковому етапі пуску ЕБ вимикачі $\mathrm{B}_{2}$ та В 3 вимкнені. Живлення на робочу СШ РУВП подають від РУ електростанції, увімкнувши вимикачі $\mathrm{B}_{6}, \mathrm{~B}_{5}$ та $\mathrm{B}_{4}$ через $\mathrm{T} 4$ резервною системою шин СШР. Генератор $\Gamma$ вмикають на паралельну роботу з ЕЕС вимикачем $\mathrm{B}_{2}$, після чого переводять живлення ВП з ПРТВП Т4 на робочі ТВП Т2, Т3.

В обох варіантах під час пуску ЕБ послідовно існуватимуть характерні квазіусталені режими схеми живлення його ВП. Для виконання завдань дослідження запропоновано зображену на рис. 2 розрахункову схему заміщення, яку складено за таких припущень та умов:

1. Не враховуються поперечні гілки схем заміщення трансформаторів.

2. Зберігаються фактичні ступені напруги із точними значеннями коефіцієнтів трансформації ідеальних трансформаторів.

3. Позначення параметрів схеми і координат режиму загальноприйняті.

4. Значення параметрів схеми i координат режиму обчислені точним методом в іменованих одиницях для відповідних ступенів напруги згідно 3 їх розташуванням у схемі, тобто без приведення до одного ступеня напруги.

5. Для обчислення напруг у відносних одиницях за базові значення для кожного ступеня прийнято: ступінь РУВП - номінальна напруга $U_{\text {ВПном }}=6$ кВ; ступінь генераторної напруги номінальна напруга генератора $U_{\text {Гном }}=15,75$ кВ; ступінь РУЕС (ЕEC) - середня номінальна напруга ступені $U_{\text {ср.ном }}=230$ кВ.

6. ЕЕС прийнята за балансувальний вузол нескінченної потужності з $E_{\mathrm{C}}=230$ кВ, тобто для всіх режимів прийнято $E_{\mathrm{C}^{*}}=1$.

7. Розрахунки проводились в системі координат лінійні напруги-струми (ЛНС) в іменованих одиницях. 
Для формування математичної моделі електрично незв'язаних підсхем системи живлення ВП ЕБ вперше уведено поняття узагальнених контурних струмів. Узагальнений контурний струм матиме різні кількісні значення в різних ділянках узагальненого контура, співвідношення між якими визначатиметься коефіцієнтами трансформації наявних ідеальних трансформаторів.

Для розрахункової схеми заміщення, наведеної на рис. 2, вибираємо два узагальнені незалежні контури $I-I$ '-I', та $I I-I I^{\prime}$ з урахуванням наявності ідеальних трансформаторів Т1, Т2 і Т3 та їх коефіцієнтів трансформації:

$K_{\mathrm{T} 1}=U_{\text {T1ном(Г) }} / U_{\text {Т1ном(С) }}<1 ; \quad K_{\mathrm{T} 2}=U_{\text {T2ном(ВП) }} / U_{\text {Т2ном(Г) }}<1 ; \quad K_{\mathrm{T} 3}=I_{\text {ТЗном(Г) }} / I_{\text {ТЗном(ВП) }}>1$.

Тоді для узагальнених контурних струмів $\dot{I}_{I}$ та $\dot{I}_{I I}$ прийнятих нами двох узагальнених незалежних контурів $I-I^{\prime}-I^{\prime \prime}$ та $I I-I I^{\prime}-$ справедливі такі співвідношення:

$$
\dot{I}_{I}^{\prime}=\dot{I}_{I} / K_{T 3} ; \quad \dot{I}_{I}^{\prime \prime}=K_{T 1} \cdot \dot{I}_{I} ; \quad \dot{I}_{I I}^{\prime}=\dot{I}_{I I} / K_{T 2}
$$

Матрично-векторне рівняння відносно вектора узагальнених контурних струмів та його компоненти матимуть вигляд:

$$
\underline{\underline{Z}}_{K} \cdot \overrightarrow{\dot{I}}_{K K}=\overrightarrow{\dot{E}}_{K K},
$$

де

$\vec{I}_{K K}=\left(\dot{I}_{I}, \dot{I}_{I I}\right)_{t}=\left(\dot{I}_{I-I^{\prime}-I^{\prime \prime}}, \dot{I}_{I I-I I^{\prime}}\right)_{t}-$ вектор узагальнених контурних струмів;

$\vec{E}_{K K}=\left(\dot{E}_{I}, \dot{E}_{I I}\right)_{t}=\left(\dot{E}_{\Gamma}-\dot{E}_{\mathrm{C}(\Gamma)}, \dot{E}_{\Gamma}\right)_{t}-$ вектор контурних ЕРС;

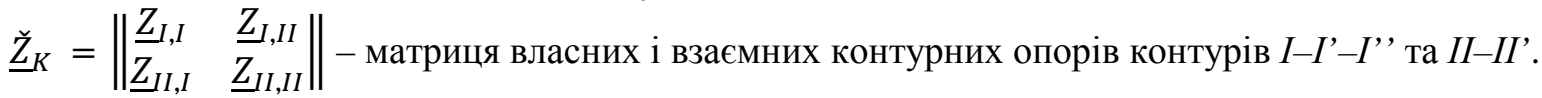

Компоненти матриці $\check{Z}_{K}$ обчислюють за виразами:

$$
\begin{aligned}
& \underline{Z}_{I, I}=\underline{Z}_{\Gamma}+\underline{Z}_{\mathrm{T} 1(\Gamma)}+K_{\mathrm{T} 1}^{2} \cdot \underline{Z}_{\mathrm{C}}+\left(\underline{Z}_{\mathrm{T} 3}+\underline{Z}_{\mathrm{P}}+\underline{Z}_{\mathrm{M}}+\underline{Z}_{\mathrm{B} \Pi}\right) / K_{\mathrm{T} 3}^{2} ; \\
& \underline{Z}_{I, I I}=\underline{Z}_{\Gamma}+\left(\underline{Z}_{\mathrm{M}}+\underline{Z}_{\mathrm{B} \Pi}\right) /\left(K_{\mathrm{T} 2} \cdot K_{\mathrm{T} 3}\right) ; \\
& \underline{Z}_{I I, I}=\underline{Z}_{\Gamma}+\left(\underline{Z}_{\mathrm{M}}+\underline{Z}_{\mathrm{B} \Pi}\right) /\left(K_{\mathrm{T} 3} \cdot K_{\mathrm{T} 2}\right) ; \\
& \underline{Z}_{I I, I I}=\underline{Z}_{\Gamma}+\left(\underline{Z}_{\mathrm{T} 2}+\underline{Z}_{\mathrm{P}}+\underline{Z}_{\mathrm{M}}+\underline{Z}_{\mathrm{B} \Pi}\right) / K_{\mathrm{T} 2}^{2} .
\end{aligned}
$$

Тоді відомі кінцеві аналітичні вирази для обчислення двох контурних струмів в нашому випадку матимуть вигляд:

$$
\begin{gathered}
\dot{I}_{I}=\left(\underline{Z}_{I, I} \cdot \dot{E}_{I}-\underline{Z}_{I, I I} \cdot \dot{E}_{I I}\right) /\left(\underline{Z}_{I, I} \cdot \underline{Z}_{I I, I I}-\underline{Z}_{I, I I} \cdot \underline{Z}_{I I, I}\right) ; \\
\dot{I}_{I I}=\left(\dot{E}_{I I}-\underline{Z}_{I I, I} \cdot \dot{I}_{I}\right) / \underline{Z}_{I I, I I} .
\end{gathered}
$$

Згідно 3 прийнятими на схемі рис. 2 додатними напрямами, значення дійсних струмів гілок обчислюємо за виразами:

$$
\begin{gathered}
\dot{I}_{\Gamma}=\dot{I}_{I}+\dot{I}_{I I} ; \dot{I}_{\mathrm{T} 2(\Gamma)}=\dot{I}_{I I} ; \dot{I}_{\mathrm{T} 3(\Gamma)}=\dot{I}_{I} ; \dot{I}_{\mathrm{T} 2}=\dot{I}_{\mathrm{T} 2(\Gamma)} / K_{\mathrm{T} 2}=\dot{I}_{I I} / K_{\mathrm{T} 2}=\dot{I}_{I I}^{\prime} ; \\
\dot{I}_{\mathrm{T} 3}=\dot{I}_{\mathrm{T} 3(\Gamma)} / K_{\mathrm{T} 3}=\dot{I}_{I} / K_{\mathrm{T} 3}=\dot{I}_{I}^{\prime} ; \dot{I}_{\mathrm{B} \Pi}=\dot{I}_{\mathrm{T} 2}+\dot{I}_{\mathrm{T} 3}=\dot{I}_{I I}^{\prime}+\dot{I}_{I}^{\prime} ; \dot{I}_{\mathrm{C}(\Gamma)}=\dot{I}_{I}=\dot{I}_{T 1(\Gamma)}=\dot{I}_{T 3(\Gamma)} ; \\
\dot{I}_{\mathrm{C}}=K_{T 1} \cdot \dot{I}_{\mathrm{C}(\Gamma)}=K_{T 1} \cdot \dot{I}_{I}=\dot{I}_{I}^{\prime \prime} .
\end{gathered}
$$

Для першого варіанта виділено чотири характерні квазіусталені режими схеми живлення ВП від РУВН (від ЕЕС) та їх реалізації.

P1.1. Режим неробочого ходу трансформаторів Т1, Т2, Т3 перед початком пуску ЕБ за відсутності навантаження ВП: генераторний вимикач $\mathrm{B}_{1}$ вимкнений, вимикач блокового трансформатора $\mathrm{B}_{2}$ увімкнений, вимикач $\mathrm{B}_{3}$ робочих вводів трансформаторів власних потреб Т2 і Т3 увімкнений, живлення на робочу систему шин РУВП подається через блоковий Т1 і робочі трансформатори ВП Т2 і Т3; вимикачі приєднань електроприймачів ВП до робочої системи шин РУВП вимкнені, тобто навантаження власних потреб відсутнє $\left(P_{\mathrm{B \Pi}}=0\right)$.

P1.2. Режим безпосередньо перед увімкненням (синхронізацією) ненавантаженого генератора Г на паралельну роботу з ЕЕС за потужності навантаження ВП на рівні 40 \% від ії номінального значення: генераторний вимикач $\mathrm{B}_{1}$ вимкнений, вимикачі приєднань електроприймачів ВП до робочої системи шин РУВП увімкнені.

Р1.3. Режим безпосередньо після увімкнення (синхронізації) ненавантаженого Г на паралельну роботу з ЕЕС за потужності навантаження ВП на рівні 40 \% від іiі номінального значення: генераторний вимикач $\mathrm{B}_{1}$ увімкнений. 
P1.4. Режим близьких до номінальних потужностей навантажень генератора $Г$ та електроприймачів ВП (досягається засобами регулювання без зміни схеми режиму Р1.3): $P_{\Gamma} \approx P_{\Gamma \text { ном }} \mathrm{i}$ $P_{\mathrm{B \Pi}} \approx P_{\text {ВП ном. }}$

Для другого варіанта виділено також чотири характерні режими схеми живлення ВП від РУ електростанції через ПРТВП та їх реалізації.

P2.1. Режим перед синхронізацією генератора $Г$ з ЕЕС: вимикачі $\mathrm{B}_{2}$ та $\mathrm{B}_{3}$ вимкнені; вимикачі $\mathrm{B}_{6}, \mathrm{~B}_{5}, \mathrm{~B}_{4}$ та вимикачі приєднань електроприймачів ВП до робочої СШ увімкнені; трансформатори Т1, Т2, Т3 - у режимі неробочого ходу; $P_{\Gamma}=0 ; P_{\text {ВП }} \approx 0,4 \cdot P_{\text {ВПном }}$ (від ПРТВП Т4).

$\mathrm{P} 2.2$. Режим після синхронізації генератора $\Gamma$ з EEC: вимикач $\mathrm{B}_{2}$ увімкнений, а вимикач $\mathrm{B}_{3}$ залишається вимкненим; $P_{\Gamma}=0 ; P_{\text {ВП }} \approx 0,4 \cdot P_{\text {ВПном }}($ від ПРТВП Т4).

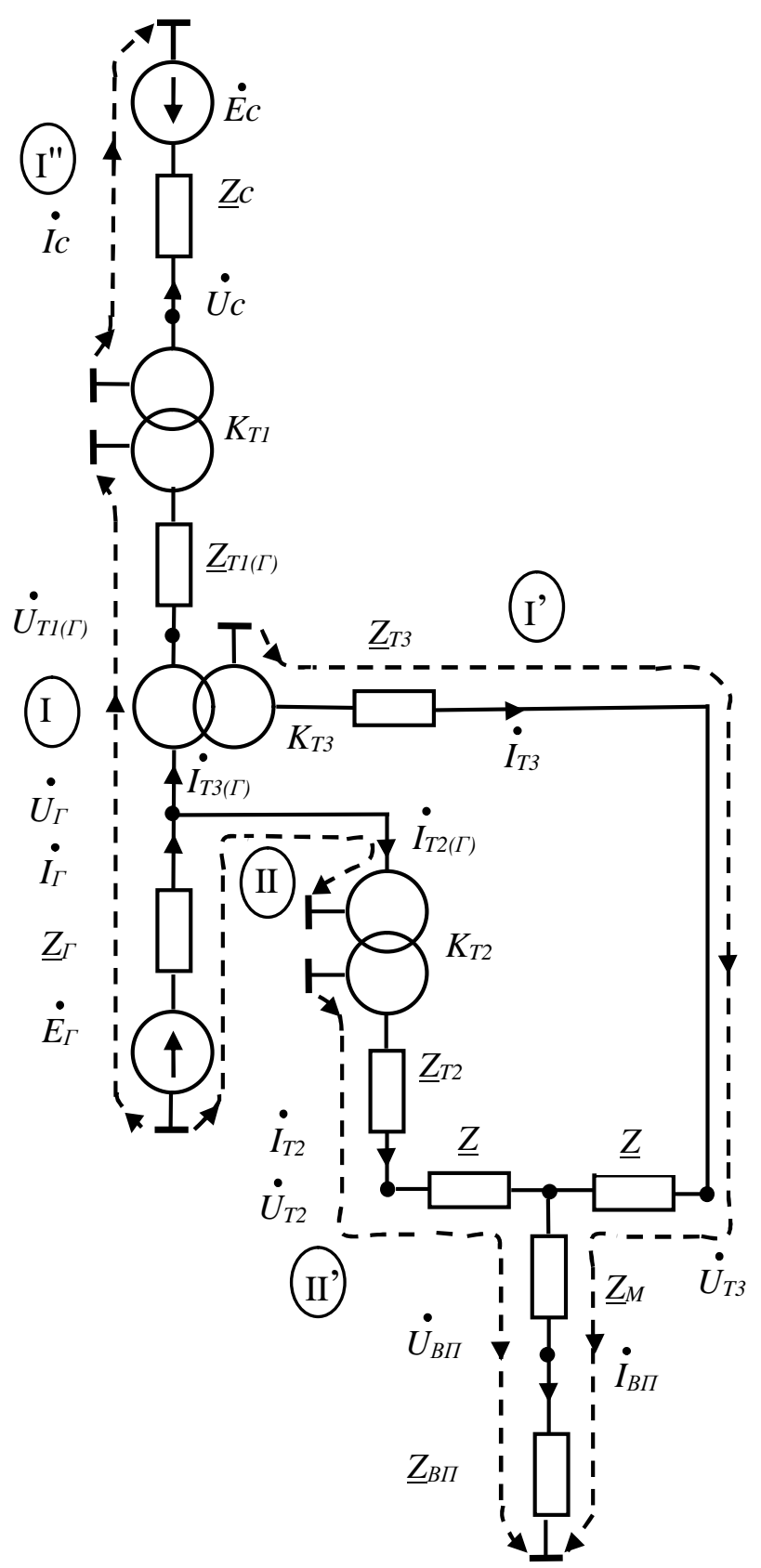

Рис. 2. Розрахункова схема заміщення ЕБ з ДРТВП
Р2.3. Режим на рівні $20 \%$ від номінального значення без зміни стану вимикачів і відповідного йому навантаження ВП перед ї перемиканням на живлення від генератора $\Gamma: P_{\Gamma} \approx 0,2 \cdot P_{\Gamma \text { ном}}$;

$$
P_{\mathrm{B \Pi}}=\left(0,4+0,6 \cdot P_{\Gamma} / P_{\text {Г ном }}\right) \cdot P_{\text {ВП ном }}=
$$$$
=0,52 P_{\text {ВП ном }} \text { (від ПРТВП Т4). }
$$

P2.4. Режим попереднього навантаження генератора Г після перемикання живлення робочої системи шин РУВП від пускорезервного трансформатора Т4 на живлення від робочих трансформаторів власних потреб Т2 і Т3: вимикач $\mathrm{B}_{3}$ увімкнений, вимикач $\mathrm{B}_{4}$ вимкнений;

$$
\begin{gathered}
P_{\Gamma} \approx 0,2 \cdot P_{\text {Гном }} \cdot P_{\text {ВП }}= \\
=\left(0,4+0,6 \cdot P_{\Gamma} / P_{\text {Гном }}\right) \cdot P_{\text {ВПном }}=
\end{gathered}
$$

$=0,52 \cdot P_{\text {ВП ном }}($ від робочих ТВП Т2 і Т3).

У варіантах 1 і 2 режими з однаковим номером 4 є різними. У варіанті 1 режим 4 це нормальний режим номінального завантаження генератора після синхронізації.

$\mathrm{У}$ варіанті 2 режим 4 виникає після синхронізації генератора та переведення живлення ВП з ПРТВП Т4 на робочі ТВП Т2, Т3. Таке переведення рекомендовано після досягнення навантаженням генератора значення $P_{\Gamma} \approx 0,2 \cdot P_{\text {Гном }}$, та відповідної йому потужності навантаження власних потреб $P_{\text {ВП }} \approx 0.52 \cdot P_{\text {ВПном. }}$

Типи, каталожні й розрахункові параметри електроустаткування досліджуваної схеми енергоблока прийнято на основі $[19,20]$.

Турбогенератор Г типу ТГВ-200M [19,

20]: $P_{\text {Гном }}=200 \mathrm{MBT;} \cos \varphi_{\text {Гном }}=0,85$;

$Q_{\text {Гном }}=124$ Мвар; $S_{\text {Гном }}=235,3 \mathrm{MB} \cdot \mathrm{A}$; $U_{\text {Гном }}=15,75 \mathrm{\kappa B} ; x_{d *}^{\prime \prime}=0,202$;

$r_{\text {ст }}=0,0013$ Ом; $\underline{Z}_{\Gamma}=0,0013+j 0,213$ Ом . 
Власні потреби ВП: $U_{\text {ВПном }}=6 \quad$ кВ; $\quad P_{\text {ВПном }}=0,08 \cdot P_{\text {Гном }}=16 \quad \mathrm{MB} \cdot \mathrm{A} ; \quad \cos \varphi \quad$ вПном $=0.7 \quad$ та $\underline{Z}_{\text {ВПном }}=1,102+j 1,124$ Ом .

Блоковий трансфоматор Т1 типу ТДЦ-250000/220 [19]:

$S_{\text {ном }}=250 \mathrm{MB} \cdot \mathrm{A} ; U_{\text {Вном }}=242 \mathrm{\kappa B}, U_{\text {Нном }}=15,75 \kappa \mathrm{B} ; U_{\mathrm{K}}=11 \% ; \Delta P_{\mathrm{K}}=650 \kappa \mathrm{\kappa} ; K_{\mathrm{T} 1}=U_{\text {Нном }} / U_{\text {Вном }}=0,0651$ та $\underline{Z}_{\mathrm{T} 1(\Gamma)}=0,0025+j 0,110 \mathrm{M}$.

Електроенергосистема ЕEC: приймаємо $E_{\mathrm{C}}=230 \mathrm{\kappa B} ; E_{\mathrm{C}^{*}}=1,0 ; S_{\mathrm{C} \text { к.3. }}=\infty$ та $\underline{Z}_{\mathrm{C}}=0$.

Робочий трансформатор власних потреб Т2 типу ТРДНС-25000/35 [19]. Для цих завдань розглядається як двообмотковий з однією еквівалентною вторинною нерозщепленою обмоткою:

$S_{\text {ном }}=25 \mathrm{MB} \cdot \mathrm{A} ; U_{\text {Вном }}=15,75 \kappa \mathrm{K} ; U_{\text {Нном }}=6,3 \kappa \mathrm{\kappa} ; U_{\mathrm{\kappa B}-\mathrm{H}}=10,5 \% ; \Delta P_{\mathrm{\kappa}}=115 \kappa \mathrm{\kappa T} ; K_{\mathrm{T} 2}=U_{\text {Нном }} / U_{\text {Вном }}=0,4$ та $\underline{Z}_{\mathrm{T} 2}=0,008+j 0,183$ Ом.

Додатковий робочий трансформатор власних потреб Т3. За основу для обчислення прийнято двообмотковий трансформатор типу ТДНС-16000/20 [19] 3 такими бажаними (після реконструкції) параметрами: $S_{\text {ном }}=16 \mathrm{MB} \cdot \mathrm{A} ; U_{\text {ном(ВП) }}=6,3 \mathrm{\kappa B} ; U_{\mathrm{\kappa}}=10 \% ; \Delta P_{\mathrm{\kappa}}=85$ кВт;

$K_{\mathrm{T} 3}=I_{\text {ТЗном }(\Gamma)} /_{\text {ТЗном(ВП) }}=6,0$ та $\underline{Z}_{\mathrm{T} 3}=0,0132+j 0,248$ Ом.

Здвосний реактор Р типу РБСГ-10-2×1600-0.20У3 [20]:

$I_{\text {ном }}=2 \times 1,6 \kappa$ к; $S_{\text {ном }}=55,4 \mathrm{MB} \cdot \mathrm{A} ; U_{\text {ном }}=10 \mathrm{\kappa B} ; \Delta P_{\text {ном.ф }}=14,3$ кВт; $x_{0,5}=0,2$ Ом; $x_{0,5 \mathrm{p}}=0,1$ Ом; $x_{\mathrm{c}}=0,6$ Ом.

Параметри схеми заміщення реактора на рис. $2: \underline{Z}=0,003+j 0,30 \mathrm{M} ; \underline{Z}_{\mathrm{M}}=-j 0,1$ Ом.

Результати комп'ютерної симуляції характерних квазіусталених режимів за першим і другим варіантами наведено в табл. 1 і табл. 2, відповідно.

Координати квазіусталених режимів першого варіанта пуску ЕБ

Таблищя 1

\begin{tabular}{|c|c|c|c|c|}
\hline & P1.1 & P1.2 & P1.3 & P1.4 \\
\hline $\begin{array}{c}\text { Величина } \\
\text { (комплексна) }\end{array}$ & $\begin{array}{c}\text { СШ РУВП від } \\
\text { ЕЕС, } \\
P_{\text {вп* }}=0\end{array}$ & $\begin{array}{c}\text { ВП від ЕЕС перед } \\
\text { синхронізацією Г, } \\
P_{\text {вп } \approx} \approx 0,4\end{array}$ & $\begin{array}{c}\text { ВП від ЕЕС після } \\
\text { синхронізації Г, } \\
P_{\text {вп* } \approx 0,4}\end{array}$ & $\begin{array}{c}\text { Близький до } \\
\text { номінального, } \\
P_{\Gamma} \approx P_{\text {Гном }}\end{array}$ \\
\hline$E_{\Gamma^{*}}$ & - & 1,0 & $1,02 \angle 0,02$ & $1,15 \angle 13,5$ \\
\hline$U_{\Gamma^{*}}$ & - & 1,0 & $1,012 \angle-0,29$ & $1,053 \angle 5,39$ \\
\hline$U_{\mathrm{T} 2(\Gamma) *}$ & 1,018 & $1,007 \angle-0,51$ & $1,012 \angle-0,29$ & $1,053 \angle 5,39$ \\
\hline$U_{\mathrm{T} 3(\Gamma) *}$ & 0,068 & $0,061 \angle-5,78$ & $0,062 \angle-4,83$ & $0,067 \angle 12,15$ \\
\hline$U_{\mathrm{T} 1(\Gamma) *}$ & 0,95 & $0,947 \angle-0,17$ & $0,951 \angle 0,01$ & $0,986 \angle 4,93$ \\
\hline$U_{\mathrm{T} 2 *}$ & 1,069 & $1,019 \angle-2,2$ & $1,028 \angle-1,89$ & $1,049 \angle 4,36$ \\
\hline$U_{\mathrm{T} 3} *$ & 1,069 & $0,957 \angle-5,6$ & $0,975 \angle-4,84$ & $1,005 \angle 7,96$ \\
\hline$U_{\mathrm{B} \Pi *}$ & 1,069 & $0,979 \angle-4,34$ & $0,992 \angle-3,81$ & $1,003 \angle 4,92$ \\
\hline$S_{\Gamma}, \mathrm{MBA}$ & - & - & $6,56+\mathrm{j} 8,84$ & $199,65+\mathrm{j} 103,89$ \\
\hline$S_{\mathrm{C}}, \mathrm{MBA}$ & - & $-6,16-j 7,32$ & $0,24+\mathrm{j} 1,56$ & $183,01+\mathrm{j} 65,91$ \\
\hline$S_{\mathrm{T} 2}, \mathrm{MBA}$ & - & $6,58+j 7,23$ & $6,28+\mathrm{j} 6,77$ & $4,57+\mathrm{j} 11,43$ \\
\hline $\mathrm{S}_{\mathrm{T} 3}, \mathrm{MBA}$ & - & $-0,44-\mathrm{j} 0,43$ & $0,024+\mathrm{j} 0,10$ & $11,56+\mathrm{j} 6,09$ \\
\hline$S_{\mathrm{B} \Pi}, \mathrm{MBA}$ & - & $6,13+j 6,26$ & $6,30+\mathrm{j} 6,42$ & $16,10+j 16,42$ \\
\hline$I_{\Gamma}, \kappa \mathrm{A}$ & - & - & $0,399 \angle-53,73$ & $7,837 \angle-22,10$ \\
\hline$I_{\mathrm{C}}, \kappa \mathrm{A}$ & - & $0,024 \angle 130,10$ & $0,004 \angle-81,42$ & $0,488 \angle-19,81$ \\
\hline$I_{\mathrm{T} 2(\Gamma),}, \mathrm{KA}$ & - & $0,369 \angle-49,90$ & $0,346 \angle-49,02$ & $0,452 \angle-63,86$ \\
\hline$I_{\mathrm{T} 3(\Gamma),}, \mathrm{A}$ & - & $0,369 \angle 130,10$ & $0,061 \angle-81,42$ & $7,506 \angle-19,81$ \\
\hline$I_{\mathrm{T} 2}, \kappa \mathrm{A}$ & - & $0,923 \angle-49,90$ & $0,864 \angle-49,02$ & $1,129 \angle-63,86$ \\
\hline$I_{\mathrm{T} 3}, \kappa \mathrm{A}$ & - & $0,062 \angle 130,10$ & $0,010 \angle-81,42$ & $1,251 \angle-19,81$ \\
\hline$I_{\mathrm{B}}, \mathrm{\kappa A}$ & - & $0,861 \angle-49,90$ & $0,873 \angle-49,38$ & $2,207<-40,60$ \\
\hline
\end{tabular}


Координати квазіусталених режимів другого варіанта пуску ЕБ

\begin{tabular}{|c|c|c|c|c|}
\hline & $\mathrm{P} 2.1$ & $\mathrm{P} 2.2$ & P 2.3 & P 2.4 \\
\hline $\begin{array}{c}\text { Величина } \\
\text { (комплексна) }\end{array}$ & $\begin{array}{c}\text { СШ РУВП від } \\
\text { ПРТВП перед } \\
\text { синхронізацією Г, } \\
S_{\Gamma}=0\end{array}$ & $\begin{array}{l}\text { СШ РУВП від ПРТВП } \\
\text { після синхронізації Г, } \\
\qquad S_{\Gamma} \approx 0\end{array}$ & $\begin{array}{c}\text { СШ РУВП від } \\
\text { ПРТВП, } \\
P_{\Gamma} \approx 0,2 P_{\text {Гном}}, \\
P_{\Gamma} \approx 40 \mathrm{MBT}\end{array}$ & $\begin{array}{c}\text { СШ РУВП від } \\
\text { ДРТВП та РТВП, } \\
P_{\Gamma} \approx 0,2 P_{\text {Гном }}, \\
P_{\text {ВП }} \approx 0,52 P_{\text {ВПном }}\end{array}$ \\
\hline$E_{\Gamma^{*}}$ & 1,02 & 1,02 & $1,05 \angle 3,2$ & $1,05 \angle 2,6$ \\
\hline$U_{\Gamma^{*}}$ & 1,02 & $1,019 \angle-0,0005$ & $1,031 \angle 1,385$ & $1,023 \angle 0,735$ \\
\hline$U_{\mathrm{T} 2(\Gamma) *}$ & 1,02 & $1,019 \angle-0,0005$ & $1,031 \angle 1,385$ & $1,023 \angle 0,735$ \\
\hline$U_{\mathrm{T} 3(\Gamma) *}$ & 0,068 & $0,068<-0,002$ & $0,072 \angle 5,179$ & $0,063 \angle-1,688$ \\
\hline$U_{\mathrm{T} 1(\Gamma) *}$ & 0,952 & $0,951 \angle-0,00038$ & $0,96 \angle 1,103$ & $0,960 \angle 0,894$ \\
\hline$U_{\mathrm{T} 2}$ * & 1,071 & $1,07<-0,001$ & $1,091 \angle 2,075$ & $1,035 \angle-0,779$ \\
\hline$U_{\mathrm{T} 3} *$ & 1,071 & $1,07<-0,001$ & $1,116 \angle 4,309$ & $0,986 \angle-2,547$ \\
\hline$U_{\mathrm{B \Pi}} *$ & $1,071 *$ & $1,07 \angle-0,001^{*}$ & $1,103 \angle 3,205^{*}$ & $0,998<-2,227$ \\
\hline$S_{\Gamma}, \mathrm{MBA}$ & - & $0,02+\mathrm{j} 1,455$ & $40,07+\mathrm{j} 21,40$ & $40,92+j 30,89$ \\
\hline$S_{\mathrm{C}}, \mathrm{MBA}$ & - & $0,02+\mathrm{j} 1,454$ & $40,04+j 20,155$ & $32,57+\mathrm{j} 20,78$ \\
\hline$S_{\mathrm{T} 2}, \mathrm{MBA}$ & - & $-0,0014-\mathrm{j} 0,104$ & $-2,86-\mathrm{j} 1,57$ & $6,11+j 7,61$ \\
\hline $\mathrm{S}_{\mathrm{T} 3}, \mathrm{MBA}$ & - & $0,0014+\mathrm{j} 0,104$ & $2,87+\mathrm{j} 1,72$ & $2,20+\mathrm{j} 1,27$ \\
\hline$S_{\mathrm{B}}, \mathrm{MBA}^{* *}$ & - & - & - & $8,31+\mathrm{j} 8,48$ \\
\hline$I_{\Gamma}, \mathrm{\kappa A}$ & - & $0,052 \angle-89,23$ & $1,614 \angle-26,72$ & $1,837 \angle-36,32$ \\
\hline$I_{\mathrm{C}}, \mathrm{\kappa A}$ & - & $0,0036 \angle-89,23$ & $0,112 \angle-26,72$ & $0,097 \angle-32,55$ \\
\hline$I_{\mathrm{T} 2(\Gamma)}, \kappa \mathrm{A}$ & - & $0,0037 \angle 90,78$ & $0,115 \angle 153,28$ & $0,363<-51,99$ \\
\hline$I_{\mathrm{T} 3(\Gamma)}, \kappa \mathrm{A}$ & - & $0,056 \angle-89,23$ & $1,730<-26,72$ & $1,491 \angle-32,55$ \\
\hline$I_{\mathrm{T} 2}, \mathrm{KA}$ & - & $0,0093 \angle 90,78$ & $0,288 \angle 153,28$ & $0,907<-51,99$ \\
\hline$I_{\mathrm{T} 3}, \kappa \mathrm{A}$ & - & $0,0093<-89,23$ & $0,288<-26,72$ & $0,248 \angle-32,55$ \\
\hline$I_{\mathrm{B} \Pi}, \mathrm{\kappa A} * *$ & - & - & - & $1,144 \angle-47,84$ \\
\hline
\end{tabular}

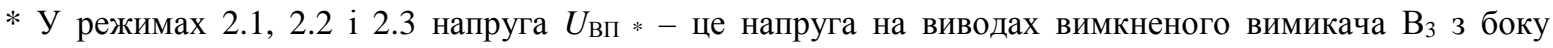
робочих ТВП Т2 і Т3 (у відносних одиницях).

** Потужність і струм навантаження ВП від генератора Г.

Результати досліджень показали, що під час пуску енергоблока послідовно виникають характерні квазіусталені режими його електричної частини, зумовлені зміною схеми та ії параметрів. Одержаний за результатами їх комп'ютерної симуляції рівень напруги на шинах розподільної устави першого ступеня трансформації системи живлення електроприймачів власних потреб з до-

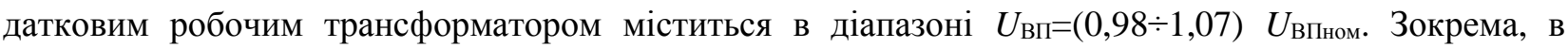
режимах завантаження генератора, близьких до номінального, значення цієї напруги практично дорівнює номінальному, і під час пускових режимів не виникають струмові перевантаження елементів системи живлення власних потреб.

\section{Висновки}

1. Застосування узагальнених контурних струмів дало змогу сформувати ефективну математичну модель нової системи живлення власних потреб з додатковим робочим трансформатором. 
Такий підхід до моделювання може бути доцільним для дослідження інших систем з електрично не зв'язаними підсхемами.

2. Результати комп'ютерного симулювання показали, що у новій схемі забезпечується рівень напруги на шинах живлення електроприймачів власних потреб, необхідний для успішних пусків енергоблока.

3. У досліджуваній схемі під час характерних пускових режимів енергоблока струмове завантаження елементів системи живлення власних потреб не перевищує їхніх номінальних значень.

4. Одержані результати досліджень пускових режимів енергоблока підтвердили можливість ефективного застосування системи живлення власних потреб з додатковим робочим трансформатором.

\section{Список літератури}

1. Электрическая часть электростанций - Схемы питания собственных нужд тепловых электростаниий. URL: https://forca.ru/knigi/arhivy/elektricheskaya-chast-elektrostanciy-33.html.

2. Собственные нужды тепловых электростаниий / Э. М. Абасова, Ю. М. Голоднов, В. А. Зильберман, А. Г. Мурзаков; под. ред. Ю. М. Голоднова. М.: Энергоатомиздат, 1991. 272 c.

3. Схеми електричних з'єднань власних потреб. URL: https://studfiles.net/preview/5199950/page:9 (дата звернення: 10.03.2018).

4. Дмитренко О. О., Заколодяжний В. В. Автоматичне введення резерву магістралі резервного живлення власних потреб атомної електростаниії. Вісник Вінницького політехнічного інституту. 2018. № 2. C. 44-50.

5. Вимоги до систем електропостачання, важливих для безпеки атомних станиій: затв. наказом Державної інспекції ядерного регулювання України від 24.12.2015 № 234. Зареєстровано в М-ві юстииіі Украӥни 16.01.2016 р. за № 78/28208. URL: https://zakon.rada.gov.иa/go/z0078-16 (дата звернення 13.09.2018).

6. [Електронний ресурс]. https://gospodarstva.com/vlasni-potrebi-elektrichnih-stantsij (дата звернення 01.04.2017).

7. Георгиади В. Х. Поведение энергоблоков ТЭС при перерывах электроснабжения собственных нужд (ч. 1). М.: НТФ “Энергопрогресс”, 2003. 80 c.

8. Yamada H. High-Voltage Direct Inverter Applied to Induced Draft Fan Motor at Takehara Thermal Power Station No. 3 of Electric Power Development Company Ltd. / H. Yamada, K. Arayama, S. Okamatsu, K. Nagata // Hitachi Review. 2004. Vol. 5. P. 121-125.

9. Tomasz Kotlicki. Poprawa efektywności energetycznej w uktadzie potrzeb własnych bloku energetycznego dużej mocy ARCHIWUM ENERGETYKI tom XLII(2012), nr 2, 185-195.

10. Mariusz Kłos, Marek Głaz, Rafat Bielas, Magdalena Błędzińska, Józef Paska, Łukasz Rosłaniec. Ocena wplywu poziomu napięcia w sieci przesyłowej na funkcjonowanie układów potrzeb wlasnych bloków energetycznych. Acta Energetica - Numer 4/25 (December 2015). P. 78-82.

11. Лисяк Г. М., Маліновський А. А., Никонеиь Л. О. Система електропостачання власних потреб енергоблока електростанції. Патент України № 39640A, 2001.

12. Лисяк Г. М., Пастух О. Р. Оиінка необхідної встановленої потужності робочих трансформаторів першого ступеня трансформації схеми підвищеної надійності електропостачання власних потреб енергоблоків електростаниій. Технічна електродинаміка. 2003. № 5. С. 50-54.

13. Лисяк Г. М., Пастух О. Р. Оиінка рівнів напруг під час усталених режимів енергоблоків $з$ додатковим робочим трансформатором власних потреб. Електроенергетичні та електромеханічні системи. 2008. № 615. С. 58-64.

14. Лисяк Г. М., Пастух О. Р. Оиінка діапазону зміни рівня напруги на шинах власних потреб схеми підвищеної надійності енергоблоків під час зовнішніх трифазних коротких замикань. Електроенергетичні та електромеханічні системи. 2001. № 435. С. 77-84.

15. Лисяк Г. М., Пастух О. Р., Скрипник О. І., Коновал В. С. Комп'ютерне симулювання усталених режсиів енергоблока електростанції з додатковим робочим трансформатором власних потреб. Вісник Наи. ун-ту “Львівська політехніка". 2003. № 487. С. 81-88.

16. Heorhiy Lysiak, Olena Pastukh, Bohdan Kharchyshyn. Physical Modeling of Power Unit in Power Plant with Auxiliary Transformer. Energy Engineering and Control Systems. 2019. No. 1. pp. 15-22, https://doi.org/10.23939/jeecs2019.01.015. 
17. Klucznik J, Dobrzyński K, Lubośny Z. Rozruch urzadzeń potrzeb własnych bloku elektrownicieplnej przy zasilaniu z elektrowni wodnej. Acta Energetica. 2016. P. 60-65.

18. Гук Ю. Б., Кобжув В. М., Черновеи А. К. Устройство, проектирование и эксплуатация схем электроснабжения собственных нужд АЭС. М.: Энергоатомиздат, 1991. 296 c.

19. Неклепаев Б. Н., Крючков И. П. Электрическая часть электростанциий и подстанций: справочные материаль для курсового и дипломного проектирования. М.: Энергоатомиздат, 1989. 608 c.

20. Ершевич В. В., Зейлигер А. Н., Илларионов Г. А. и др.: под ред. С. С. Рокотяна и И. М. Шапиро. Справочник по проектированию электроэнергетических систем. М.: Энергоатомиздат, 1985. 352 с.

\section{References}

1. Эlektrycheskaia chast эlektrostantsyi - Skhembl pytanyia sobstvennblkh nuzhd teplovblkh эlektrostantsyi. URL: https://forca.ru/knigi/arhivy/elektricheskaya-chast-elektrostanciy-33.html.

2. Sobstvennyye nuzhdy teplovykh elektrostantsiy. E. M. Abasova, Yu. M. Golodnov, V. A. Zil'berman, A. G. Murzakov; pod. red. YU. M. Golodnova. M.: Energoatomizdat, 1991. 272 s.

3. Skhemy elektrychnykh ziednan vlasnykh potreb. URL: https://studfiles.net/preview/5199950/page:9 (data zvernennia: 10.03.2018).

4. Dmytrenko O. O., Zakolodiazhnyi V. V. Avtomatychne vvedennia rezervu mahistrali rezervnoho zhyvlennia vlasnykh potreb atomnoi elektrostantsii. Visnyk Vinnytskoho politekhnichnoho instytutu. 2018. No. 2. S. 44-50.

5. Vymohy do system elektropostachannia, vazhlyvykh dlia bezpeky atomnykh stantsii: zatv. nakazom Derzhavnoi inspektsii yadernoho rehuliuvannia Ukrainy vid 24.12.2015 No. 234. Zareiestrovano v M-vi yustytsii Ukrainy 16.01.2016 r. za № 78/28208. URL: https://zakon.rada.gov.ua/go/z0078-16 (data zvernennia 13.09.2018).

6. Elektronnbi resurs: https://gospodarstva.com/vlasni-potrebi-elektrichnih-stantsij (data zvernennia 01.04.2017).

7. Heorhyady V. Kh. Povedenye эnerhoblokov TЭS pry pererblvakh Эlektrosnabzhenyia sobstvennblkh nuzhd (ch. 1). M.: NTF “Эnerhoprohress”, 2003. 80 s.

8. Yamada H. High-Voltage Direct Inverter Applied to Induced Draft Fan Motor at Takehara Thermal Power Station No. 3 of Electric Power Development Company Ltd. / H. Yamada, K. Arayama, S. Okamatsu, K. Nagata // Hitachi Review. 2004. Vol. 5. P. 121-125.

9. Tomasz Kotlicki. Poprawa efektywności energetycznej w układzie potrzeb własnych bloku energetycznego dużej mocy ARCHIWUM ENERGETYKI tom XLII(2012), nr 2, 185-195.

10. Mariusz Kłos, Marek Głaz, Rafał Bielas, Magdalena Błędzińska, Józef Paska, Eukasz Rosłaniec. Ocena wpływu poziomu napięcia $w$ sieci przesyłowej na funkcjonowanie układów potrzeb własnych bloków energetycznych. Acta Energetica - Numer 4/25 (December 2015).P. 78-82.

11. Lysiak H. M., Malinovskyi A. A., Nykonets L. O. Systema elektropostachannia vlasnykh potreb enerhobloka elektrostantsii. Patent Ukrainy No. 39640A, 2001.

12. Lysiak H. M., Pastukh O. R. Otsinka neobkhidnoi vstanovlenoi potuzhnosti robochykh transformatoriv pershoho stupenia transformatsii skhemy pidvyshchenoi nadiinosti elektropostachannia vlasnykh potreb enerhoblokiv elektrostantsii. Tekhnichna elektrodynamika. 2003. No. 5. S. 50-54.

13. Lysiak H. M., Pastukh O. R. Otsinka rivniv napruh pid chas ustalenykh rezhymiv enerhoblokiv $z$ dodatkovym robochym transformatorom vlasnykh potreb. Elektroenerhetychni ta elektromekhanichni systemy. 2008. No. 615. S. 58-64.

14. Lysiak H. M., Pastukh O. R. Otsinka diapazonu zminy rivnia napruhy na shynakh vlasnykh potreb skhemy pidvyshchenoi nadiinosti enerhoblokiv pid chas zovnishnikh tryfaznykh korotkykh zamykan. Elektroenerhetychni ta elektromekhanichni systemy. 2001. No. 435. S. 77-84.

15. Lysiak H. M., Pastukh O. R., Skrypnyk O. I., Konoval V. S. Kompiuterne symuliuvannia ustalenykh rezhymiv enerhobloka elektrostantsii $z$ dodatkovym robochym transformatorom vlasnykh potreb. Visnyk nats. un-tu “Lvivska politekhnika”. 2003. No. 487. S. 81-88.

16. Heorhiy Lysiak, Olena Pastukh, Bohdan Kharchyshyn. Physical Modeling of Power Unit in Power Plant with Auxiliary Transformer. Energy Engineering and Control Systems. 2019. No. 1. pp. 15-22: https://doi.org/10.23939/jeecs2019.01.015.

17. Klucznik J, Dobrzyński K, Lubośny Z. Rozruch urzadzeń potrzeb własnych bloku elektrownicieplnej przy zasilaniu z elektrowni wodnej. Acta Energetica. 2016. P. 60-65.

18. Huk Yu. B., Kobzhuv V. M., Chernovets A. K. Ustroistvo, proektyrovanye y эkspluatatsyia skhem эlektrosnabzhenyia sobstvennblkh nuzhd AЭS. M.: Эnerhoatomyzdat, 1991. 296 c. 
19. Neklepaev B. N., Kriuchkov Y. P. Эlektrycheskaia chast эlektrostantsyi y podstantsyi: spravochnble materyalbl dlia kursovoho y dyplomnoho proektyrovanyia. M.: Эnerhoatomyzdat. 1989. 608 s.

20. Ershevych V. V., Zeilyher A. N., Yllaryonov H. A. y dr.: pod red. S. S. Rokotiana y Y. M. Shapyro. Spravochnyk po proektyrovanyiu эlektroэnerhetycheskykh system. M.: Эnerhoatomyzdat. 1985. 352 s.

G. Lysiak,
Lviv Polytechnic National University,
Department of Electric Power Engineering and Control Systems,
georhii.m.lysiak@lpnu.ua

A. Malinovskyi,

Lviv Polytechnic National University, Department of Electric Power Engineering and Control Systems, anton.a.malinovskyi@lpnu.ua

\author{
O. Pastukh \\ Lviv Polytechnic National University, \\ Department of Electric Power Engineering and Control Systems, \\ olena.r.pastukh@1pnu.ua
}

CC Lysiak G., Malinovskyi A., Pastukh O., 2021

The efficiency of operation of power units of powerful thermal and nuclear power plants is largely determined by the reliability of power supply systems for their own needs. The main requirements for such systems are maintaining the required voltage level on the busbars of the distribution charters of their own needs and reduction of the time of forced power outages. Ensuring these requirements by the Ukrainian energy sector is complicated by the fact that most of its power plants are operated for a long time, and their equipment is significantly worn out. In such circumstances it's important to develop and study new circuits and technical solutions for power systems of own needs of block power plants. The modes of the power unit during its start-up with the use of an additional working auxiliary transformer of own needs are investigated in the work. The method of switching on such an auxiliary transformer ensures its operation in the mode of the current source set by the load of the power unit. This makes it possible to maintain a required level of voltage on the busbars of the units of own needs of the power generator both in long use and during emergency modes in the external electrical network. Previously conducted research has shown that when the power supply modes are loaded, the voltage on the busbars of own needs is also maintained at a high enough level, which improves the static and dynamic stability of such modes compared to traditional power supply schemes of own needs. For completeness of information about the new power supply system of own needs it is necessary to investigate its modes for two variants of start-up of the power unit, which is the subject of this work. The calculated scheme of substitution of the system of own needs for both variants of start-up is substantiated, the corresponding mathematical model is formed and realized. Analysis of obtained results showed that during the start-up modes a proper voltage level on the busbars of the distribution charter of the first stage of transformation of the power supply circuit of electric receivers of own needs is provided. With that current loading of the elements in each of the characteristic modes does not exceed the corresponding nominal values. Thus, the efficiency and expediency of the introduction of the power supply scheme of the power unit with an additional working transformer of own needs is confirmed.

Key words: power unit; generator; transformer; own needs; switch; start-up; simulation; steady state; synchronization. 